\title{
Feeding ecology of the crab Cancer polyodon in La Herradura Bay, northern Chile. I. Feeding chronology, food intake, and gross growth and ecological efficiency
}

\author{
Matthias Wolff ${ }^{1}$, Gerardo Cerda $^{2}$ \\ ${ }^{1}$ Center for Tropical Marine Ecology, Universitätsallee GW 1/A, W-2800 Bremen 33, Germany \\ ${ }^{2}$ Universidad del Norte, Casilla 117, Coquimbo, Chile
}

\begin{abstract}
Feeding activity pattern and food intake of the crab Cancer polyodon were determined from crab stomach samples taken at 3 to $4 \mathrm{~h}$ intervals on 2 days per season in 1988 and 1989. The gross growth efficiency $\left(K_{1}\right)$ and the ecological (= population production) efficiency (EE) were calculated in conjunction with growth and production data from a previous study. C. polyodon feeds at night and to a lesser extent during the day. Feeding chronology differed markedly among seasons: in winter, night feeding lasted about twice as long (13 to $15 \mathrm{~h}$ ) as in spring, but maximum stomach fullness reached only $0.35 \%$ BW (body weight) compared to $0.62 \% \mathrm{BW}$ in spring. Summer feeding resembled the spring pattern and autumn feeding the winter pattern. Daily food intake was estimated from the stomach content data and a laboratory-derived evacuation rate using the Elliott \& Persson model. Daily rations increased from $2.8( \pm 0.71) \% \mathrm{BW}$ in winter to $4.4( \pm 0.64) \% \mathrm{BW}$ in summer and decreased to 2.7 ( \pm 0.37 ) \% BW in autumn (annual average: $3.19 \% \mathrm{BW}$ ). $K_{1}$ (weight gain as \% of total food ingested) was lower for females (5.3) than for males (10.3), as females convert a high fraction of ingested food into egg production instead of growth. EE [(population biomass production)/(food ingested)] was estimated at $17.8 \%$.
\end{abstract}

\section{INTRODUCTION}

Cancer polyodon is a shallow-water brachyuran crab distributed from Equador to southern Chile. It is the largest and most common of a variety of crab species inhabiting the coastal waters of Peru and Chile, where it has been fished by divers and captured with traps for many decades. It is known as a predator of clams and scallops (DiSalvo et al. 1984, Augsburger \& Vega 1989) and is suspected to be an important regulator of scallop Argopecten purpuratus recruitment (Wolff 1987). Most published reports on natural feeding of brachyuran crabs have focussed on the dietary range and shown cangrid crabs to be food generalists, preying upon small molluscs and crustaceans of limited mobility (Elner 1981, Williams 1981. 1982, Morales \& Antezana 1983, Elner et al. 1985, Haddon \& Wear 1987, Rangeley \& Thomas 1987. among others). Ontogenetical, geographical, seasonal and sex differences in the dietary range have also been reported (Hill 1976, Gotshall 1977, Jewett \& Feder 1982, Laughlin 1982, Stevens et al. 1982, Perez \& Bellwood 1988). Some authors have described the feeding technique of the crabs (Elbing et al. 1964, Elner 1978, Zipser \& Vermeij 1978, Asson-Batres 1986, Davidson 1986); others have analysed crab feeding in the light of optimal foraging theory (Elner \& Hughes 1978, Morales \& Antezana 1983, Chilton \& Bull 1986, Rangeley \& Thomas 1987).

The focus of the investigation presented here was the determination of feeding chronology, daily food intake, gross growth efficiency and ecological efficiency of Cancer polyodon. The study was part of a research program aimed at assessing the functional role of $C$. polyodon in the shallow-water community of La Herradura Bay, Chile. The population dynamics of 
this species have been characterized by Wolff \& Soto (1992). An analysis of the food spectrum will be presented later.

Previous diving observations by us have shown that Cancer polyodon forage during the night, while they seem to rest during daylight hours, buried in the sand. Based on this observation we addressed the following questions: Are the crabs exclusively night feeders? Is the feeding behaviour reflected in the stomach content over the course of a day? How do seasonal changes in water temperature and night length affect their feeding behaviour and daily rations? We conducted a laboratory study on gastric evacuation and calculated the daily rations based on this rate and on the stomach content data of the field-collected specimens, using the model of Elliott \& Persson (1978).

\section{MATERIAL AND METHODS}

Sampling and sample treatment. On 2 days per season in 1988-89, 7 samples of 15 crabs each were hand-collected by a diver within the study area (Fig. 1) at 3 to $4 \mathrm{~h}$ intervals, at a water depth of 5 to $8 \mathrm{~m}$. Immediately after collection, moulting and eggcarrying specimens were sorted out and returned to the water; the remaining specimens were killed by oral

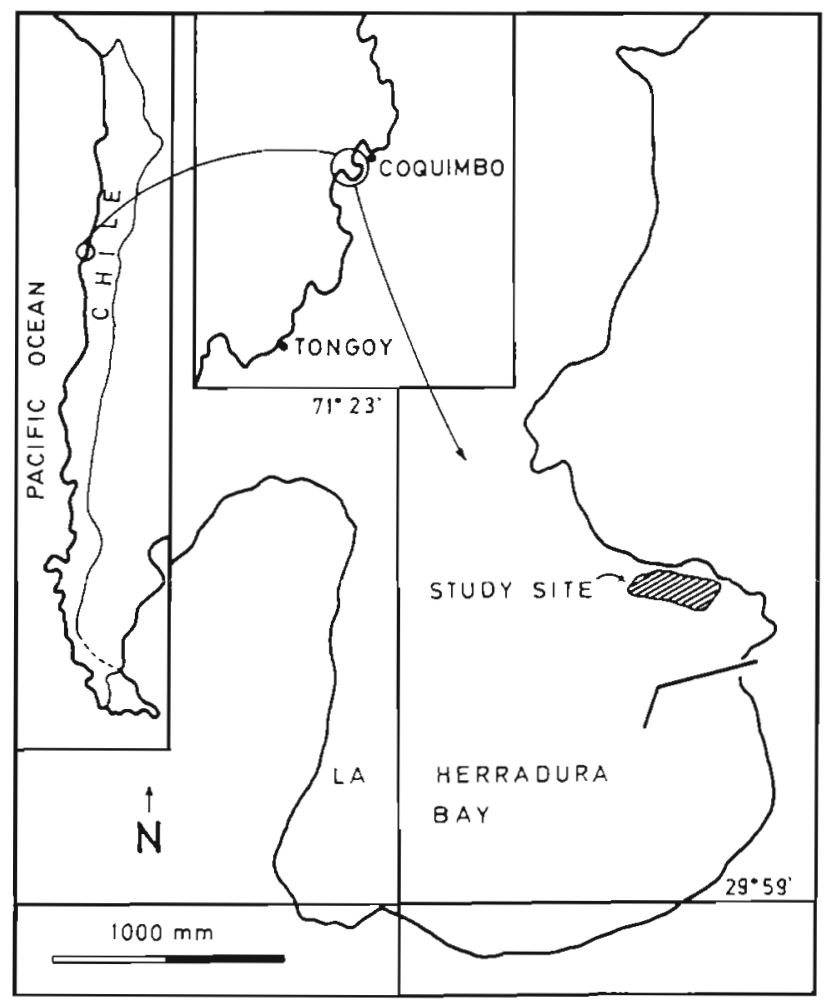

Fig. 1. La Herradura Bay, Chile, with study site injection of formalin (10\%), stored in plastic bags and transferred to the laboratory for analysis. The crabs were sexed, the carapace width (CW) was measured to the nearest $0.1 \mathrm{~mm}$ with a calliper and the fresh weight was registered to the nearest $0.1 \mathrm{~g}$. Subsequently the carapace was separated from the abdomen and the stomach was extracted and bled on absorbing paper for several minutes to eliminate excess liquid. The stomach was then emptied and the content weighed to the nearest $0.1 \mathrm{~g}$

Determination of gastric evacuation rate. Six similarsized crabs (average CW $=115 \mathrm{~mm}$ ) were kept individually in $30 \mathrm{l}$ tanks of seawater $\left(14.5 \pm 0.5^{\circ} \mathrm{C}, 35 \% \mathrm{~S}\right)$ and fed with clam meat [1.5\% of body weight (BW)]. Only those crabs that had eaten all the food offered within $15 \mathrm{~min}$ were subsequently used for the experiment. After intervals of $1.5,3,4.5$ and $6 \mathrm{~h}, 1 \mathrm{crab}$ was sacrificed to determine the stomach content. This experiment was repeated 10 times and the stomach contents after each interval were averaged. These averages were used to calculate the gastric evacuation rate (for each interval) from the following equation:

$$
S_{t}=S_{0} \mathrm{e}^{-R_{t}}
$$

where $S_{i}$ and $S_{0}$ are the stomach contents at time $t$ after food ingestion and at the start of evacuation, and $R_{l}$ is the gastric evacuation rate $\left(\mathrm{h}^{-1}\right)$. The $R$ values of each time interval were averaged and a confidence interval calculated.

In addition, we calculated $R$ values from the steepest parts of the descending portion of the feeding curves $(R=$ underlined numbers in Fig, 2) assuming that within these intervals only evacuation had occurred, and compared these values with the laboratoryderived rate.

Daily rations $\left(r_{d}\right)$ were calculated from the laboratory-derived evacuation rate and the Elliott \& Persson (1978) model:

$$
r_{\mathrm{d}}=\sum_{1}^{n} C_{\Delta t}
$$

where $C_{\lambda l}=$ quantity of food consumed during an interval $\Delta t$ between 2 successive sampling times $t$ and $t+1$, and $n=$ number of intervals per day. In our study there were always 7 such intervals. $C_{\lambda t}$ is defined as:

$$
C_{1 t}=R T\left(S_{t+1}-S_{t} \mathrm{e}^{-R T}\right) /\left(1-\mathrm{e}^{-R T}\right)
$$

where $S_{t+1}$ and $S_{t}=$ mean stomach contents at 2 successive sampling times; $R=$ evacuation rate; and $T=$ interval length in hours

Computation of standard deviation for daily ration estimates. The errors around the daily ration estimates from the Elliott \& Persson model were computed using a method known as 'bootstrap' (Efron 1981). This non- 
parametric method can be applied when the data are not normally distributed (such as the stomach contents in the present case) and even when the underlying distribution of the parameter is unknown. A necessary assumption of this method is that the original sample is representative for the population from which it is drawn. Following this method random subsamples (of the original sample size) were repeatedly taken from each sample (obtaining each time similar but not identical averages for stomach content at a sampling time), and Eq. 3 was calculated. This procedure was repeated 1000 times, producing a frequency distribution of daily rations from which the average values and standard deviations were computed.

Gross growth efficiency $\left(K_{1}\right)$ and ecological efficiency (EE). Daily weight increments of female and male Cancer polyodon were calculated from the following equations (Wolff \& Soto 1992):

$$
\text { Males: } \begin{aligned}
C W_{l} & =198\left(1-\mathrm{e}^{-0.54(t-0.25)}\right) ; \\
W_{l} & =0.00013 \mathrm{CW}_{1}^{3096} \\
\text { Females: } \quad \mathrm{CW}_{l} & =160.5\left(1-\mathrm{e}^{-0.57(t-0.25)}\right) ; \\
W_{l} & =0.00050 \mathrm{CW}_{l}^{2809}
\end{aligned}
$$

where $\mathrm{CW}_{t}$ and $W_{t}=$ carapace width $(\mathrm{m})$ and wet weight $(g)$ repectively at age $t(y r)$.

For the calculation the weight of an average crab of $115 \mathrm{~mm}$ CW (Wolff \& Soto 1992) was determined, its size increment $\mathrm{d}^{-1}$ was calculated and this size was then re-transformed into weight. $K_{1}$ was then estimated as follows:

$$
K_{1}=\frac{\text { (daily weight increment, } g \text { wet } w \mathrm{t} \text { ) }}{\text { (daily ration, } \mathrm{g} \text { wet } \mathrm{wt} \text { ) }}
$$

EE was calculated as:

$$
\mathrm{EE}=Z B r_{\bar{a}}
$$

where $Z$ and $B=$ average instantaneous mortality rate $\left(\mathrm{yr}^{-1}\right)$ of the population and the average annual biomass, estimated as 2.07 and $637 \mathrm{~kg}$ respectively (Wolff \& Soto op. cit.); and $r_{\mathrm{a}}=$ annual amount of food ingested, which is given by $B \times$ (daily food consumption in $\% B W J \times 365$.

\section{RESULTS}

\section{Feeding pattern}

The average stomach fullness of specimens collected showed a cyclic pattern for all days sampled (Fig. 2). The general pattern was similar for the 2 days per season but differed markedly among seasons. Maximum stomach content occurred earlier at night and was higher in spring and summer $(0.6$ to $0.7 \% \mathrm{BW})$ than in winter and autumn $(0.4$ to $0.5 \% \mathrm{BW})$. The

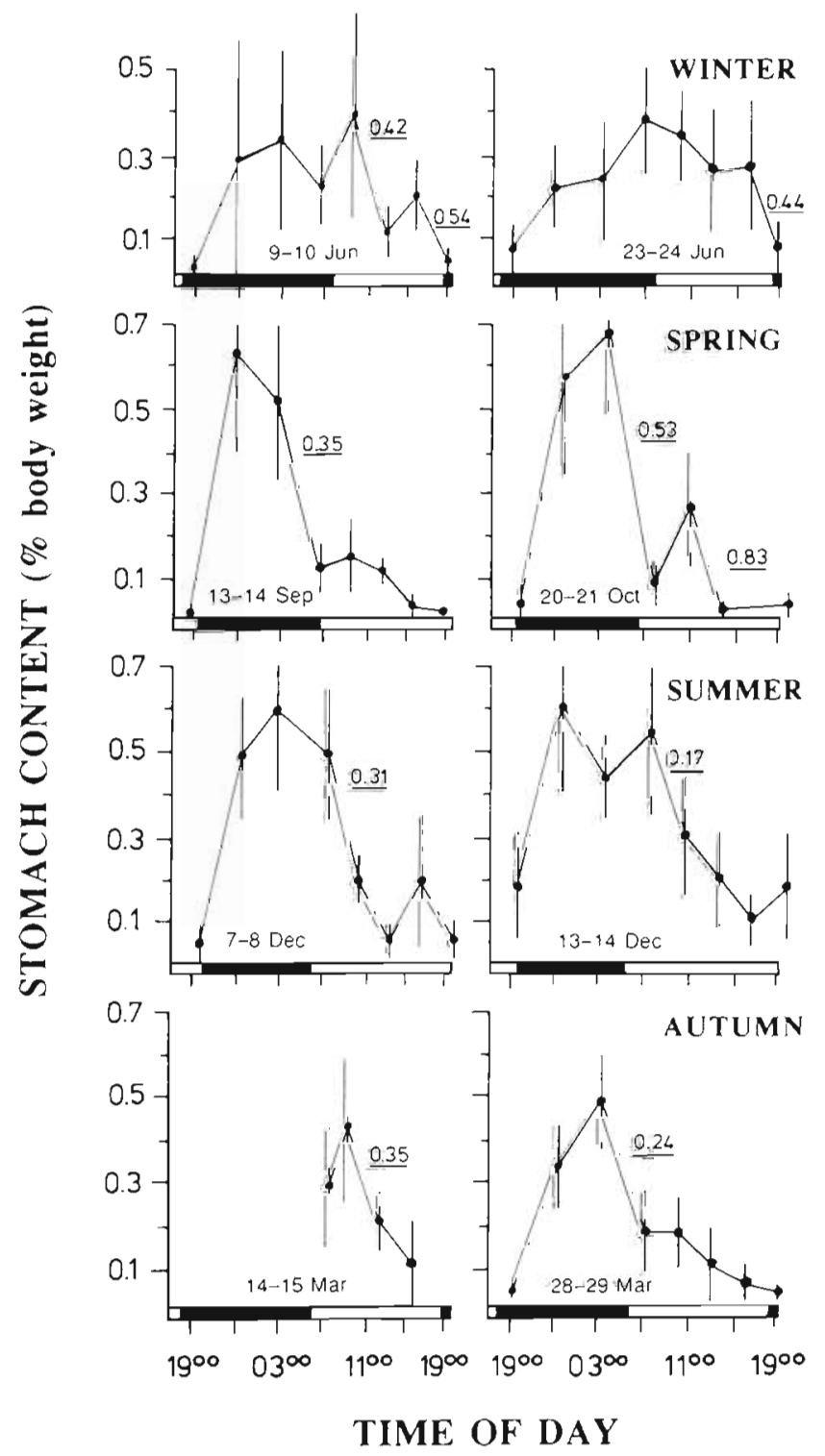

Fig. 2. Cancer polyodon. Average stomach content ( \pm 1 SE) at different times on 2 days per season (austral winter, spring and summer 1988, and autumn 1989). Underlined numbers are calculated evacuation rates, $R$, between 2 sampling times assuming no food intake; black and white bars on horizontal axes show length of night and day

highest feeding activity occurred during the night hours but daytime feeding also occurred. Lowest stomach contents were generally found just before sunset.

\section{Daily ration estimates}

Fig. 3 shows the gastric evacuation curve and the evacuation rate $(R=0.506$ ) obtained for the laboratoryfed specimens. Daily rations increased from winter 


\begin{tabular}{|c|ccccc|}
\hline & \multicolumn{5}{|c|}{ TIME $(h)$} \\
\cline { 2 - 6 } & 0 & 1.5 & 3.0 & 6.5 & 6.0 \\
\hline FOOD AS \% OF & & & & & \\
INITIAL MEAL. & 95.99 & 55.29 & 26.53 & 9.59 & 1.35 \\
s.d. & 5.11 & 16.03 & 17.03 & 12.94 & 3.03 \\
$n$ & 8 & 10 & 8 & 9 & 11 \\
\hline
\end{tabular}

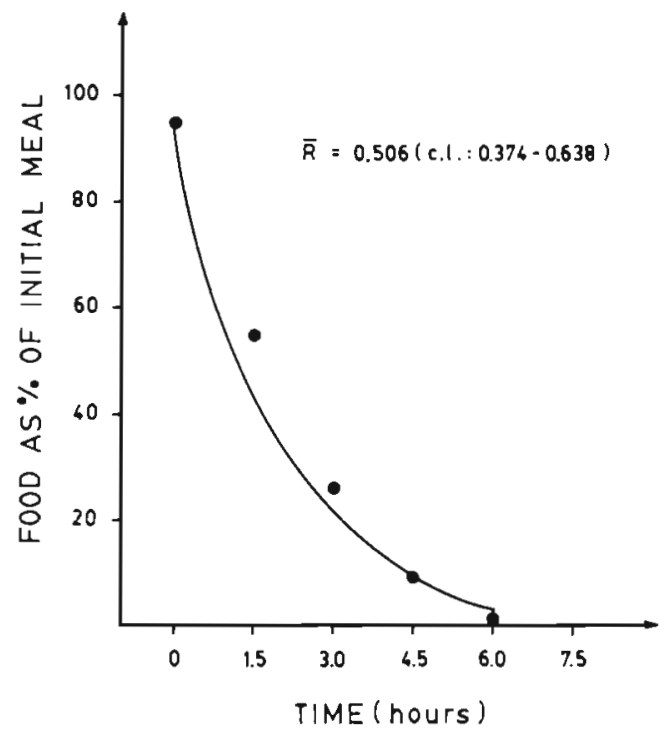

Fig. 3. Cancer polyodon. Gastric evacuation curve calculated from laboratory-fed specimens at $14 \pm 0.5^{\circ} \mathrm{C}$

through spring and summer, and decreased thereafter (Fig. 4). They were significantly different ( $t$-test, $p<0,05)$ between all seasons and days, except for the last winter and first spring day $(t=1.2$; df $=999$, $p<0.05$ ). The annual average was $3.19 \%$ BW (Fig. 4).

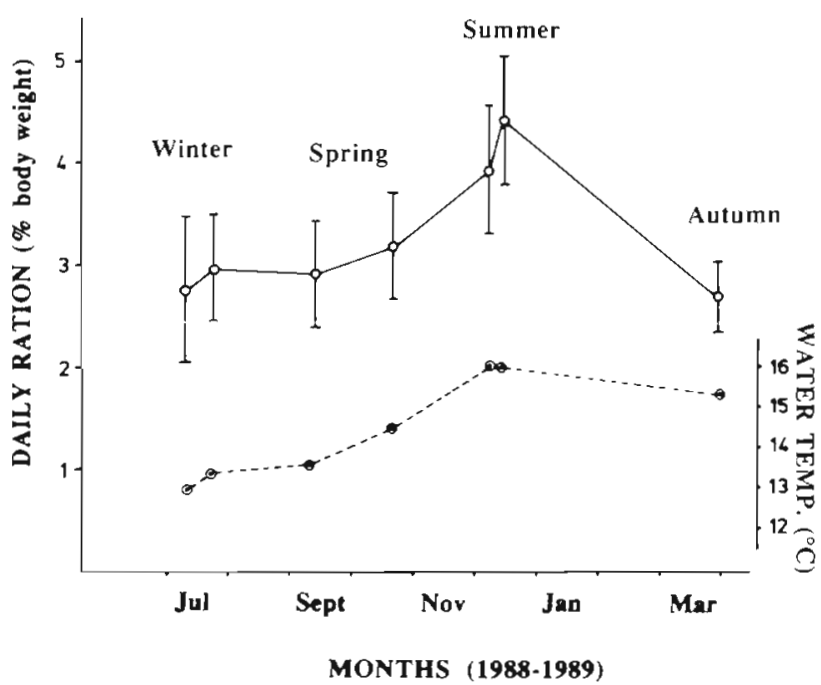

Fig. 4. Cancer polyodon. Seasonal changes in daily ration ( \pm 1 SD), calculated for each sampling day (upper curve) in relation to in situ temperature (lower curve)

\section{Gross growth and ecological efficiency}

According to the growth curves and size-weight relationships for both sexes (see above) a female of $115 \mathrm{~mm} \mathrm{CW}$ increases its body weight by about $0.52 \mathrm{~g} \mathrm{~d}^{-1}$ at a body weight of $307 \mathrm{~g}$. Using our average ration estimate of $3.19 \% \mathrm{BW}, K_{1}$ can be calculated as follows:

$$
\begin{aligned}
& K_{1}(\text { females })=100[0.52 \mathrm{~g} /(307 \times 0.0319)]=5.3 \% \\
& K_{1}(\text { males })=100[1.03 \mathrm{~g} /(312 \times 0.0319)]=10.3 \%
\end{aligned}
$$

Using Eq. 5 we obtain:

$$
\mathrm{EE}=100(2.07 \times 637) /(637 \times 0.0319 \times 365)=17.8 \%
$$

\section{DISCUSSION}

\section{Feeding pattern and food intake estimates}

Our initial assumption that Cancer polyodon feeds only at night and rests during the daytime was shown to be erroneous, as minor feeding was also found during the day (Fig. 2). The highest feeding activity occurs over the night hours, however, and most crabs appear to cease feeding at sunrise or shortly beforehand, then start again when the food is evacuated, which takes about 6 h (Fig. 3). Crabs that cease feeding at sunrise may thus start feeding again in the early afternoon hours. This is partly confirmed by our results (Fig. 2).

The seasonal variation in duration and intensity of night-time feeding followed the changes in water temperature and night length over the year (Fig. 4). It seems that at increasing temperatures in spring (and possibly also due to the shortening of the night) crabs feed more actively during the initial night hours, resulting in faster food saturation and a shortened night feeding period. A similar feeding pattern prevails in summer, when temperatures are highest (Fig. 4). The total daily food intake (Fig. 4) also showed a clear relation with the water temperature, except for the autumn estimate, which was lower than the 2 winter estimates even though temperature in autumn was higher than in spring.

This could be explained by a depletion of the crabs' food source during late summer and autumn, when crab densities are highest (Wolff \& Soto 1992). The abrupt decrease in density by about $60 \%$ at the end of autumn is also indicative of this. Virnstein (1977) reported lowest faunal densities of shallow-water subtidal communities in Chesapeake Bay, USA, in late summer and fall, after crabs and fish had been feeding on the infauna, and highest densities in winter and spring when these predators were absent or less 
active. Dare \& Edwards (1976) and DiSalvo et al. (1984) reported on the capacity of cangrid crabs (Carcinus maenas and Cancer polyodon respectively) to detect dense patches of prey and to aggregate quickly. This capacity and the high daily rations suggest that C. polyodon and probably cangrid crabs in general are extremely efficient regulators of their benthic prey's abundances.

Stomach fullness was highly variable among individuals (see SE bars in Fig. 2) and cannot be treated like a normally distributed data set. Individual success in finding and ingesting food is not only a function of the crabs' activity but also of competition among crabs, which increases with crab density. During night diving it was observed that specimens holding a prey item were attacked by other crabs trying to take the prey away; other specimens aggressively lifted their chela against one another. This agrees with observations of Scheibling (1984) on Cancer irroratus from Nova Scotia, who found that crabs fought for possession of prey and that, out of 8 crabs attracted to a piece of bait, only 1 fed at a time. His observations were also made at the end of summer, the time of highest crab densities. Such resulting high variability in the stomach contents among individual specimens can be adequately handled with the bootstrap method, as this study shows. By the use of the random resampling procedure, the variability of the original individual stomach contents in a sample is taken into account and is reflected in the variability of the resulting mean values which are used for the daily ration estimates and the corresponding error estimates.

Our estimates of daily food intake were obtained using a constant, laboratory-derived evacuation rate at a water temperature of $14 \pm 0.5^{\circ} \mathrm{C}$. As evacuation (and feeding) is temperature-dependent, $R$ will vary among the seasons with in situ temperature. However, this variation was probably small, as the temperature range among the sampling days was narrow (13.0 to $16.0^{\circ} \mathrm{C}$ ). Fig. 2 gives some indication that our laboratory-derived $R$ value $(0.506)$ is a reasonable estimate for the in situ rate, as the $R$ values obtained from the steepest parts of the descending portion of the feeding curves (Fig. 2) ranged from 0.17 to 0.86 with an average around 0.40 . Two values $(0.54,0.53)$ were near the laboratory-derived rate.

This study is the first to estimate daily rations of adult cangrid crabs in the field, and consequently references for direct comparisons of daily food uptake are lacking. Some authors, however, have reported on the predation potential of cangrid crabs. Lake et al. (1987) found that Cancer pagurus $(10.5 \mathrm{~cm} \mathrm{CW})$ consumes 25 to 31 Pecten maximus of $5 \mathrm{~cm}$ shell height and 71 to 85 $P$. maximus of $4 \mathrm{~cm}$ shell height within $5 \mathrm{~d}$. Scheibling (op. cit.) reported predation rates of 1 sea urchin $\mathrm{crab}^{-1} \mathrm{~d}^{-1}$ and 3.2 mussels $(3$ to $4 \mathrm{~cm}$ shell length) $\mathrm{crab}^{-1} \mathrm{~d}^{-1}$ for Cancer irroratus (60 to $100 \mathrm{~mm} \mathrm{CW}$ ) in the laboratory. The latter amounts to ca $5.3 \%$ BW assuming $150 \mathrm{~g} \mathrm{BW}$ for a crab of $80 \mathrm{~mm}$ CW (after Krouse 1972) and $2.5 \mathrm{~g}$ as the weight of the mussels. This rough estimate is similar to our daily ration estimates for the summer period.

Daily rations of cangrid crabs cannot be generalized to other crustaceans. For adult lobsters Homarus americanus, Jahnig (1973) reported daily rations $<1 \%$ BW to maintain their slow growth. Branford (1979) obtained values in the 0.5 to $1.5 \%$ range. These reports and our results suggest substantial differences in daily rations between crabs and lobsters and they should not be grouped into quantitative ecosystem box models, as has been done before (Polovina 1984).

\section{Gross growth efficiency and ecological efficiency}

The $K_{1}$ values of our study $(5.3$ and $10.3 \%$ for females and males respectively) are low compared to the 20 to $30 \%$ value reported by Barnes \& Mann (1980) for macroinvertebrates of temperature waters. They are also lower than those for most fish, which usually range from 15 to $30 \%$ (Bardach et al. 1972, Caddy \& Sharp 1986). Lane et al. (1979), however, calculated lower $K_{1}$ values of $12 \%$ for the benthic-feeding diamond turbot Hypsopsetta guttulata ( $>25 \mathrm{~g}$ ), assuming $80 \%$ digestion of ingested food. In Cancer polyodon, a significant proportion of the stomach content is made up of undigestable hard parts and sand (we estimate this to be about $40 \%$ ), so that only a part of the ingested food can be digested. However, $K_{1}$ values are intended to express weight gain as \% of total food ingested, without differentiating digestible and nondigestible components.

The difference in the $K_{1}$ values between sexes is explained by the fact that females convert a significant fraction of ingested food into egg production instead of somatic growth. Paul \& Fuji (1989), for example, found that female Chionoecetes bairdi allocated over $20 \%$ of their energy to their egg clutches

According to our findings, about $18 \%$ of the food ingested by the crab population was converted into population biomass. Based on the population biomassper-area estimate of $637 \mathrm{~kg}$ per $5964 \mathrm{~m}^{2}$ (Wolff \& Soto 1992), the crabs should have removed about $1.25 \mathrm{~kg}$ of their prey $\mathrm{m}^{-2} \mathrm{yr}^{-1}$. Our EE estimate is near the $20 \%$ value for overall efficiency for most marine benthic invertebrates (10 to $30 \%$ ) (Mann 1982).

The results of the present study indicate that the food ingested by Cancer polyodon is more efficiently converted into population biomass than individual bio- 
mass due to the high population turnover $(Z=2.07)$ compared to temperate invertebrates of similar sizes (Mann 1982). This might be explained by the almost constant recruitment of juveniles to the adult population (Wolff \& Soto op. cit.) and the compensatory 'thinning out' through cannibalism. This strategy not only keeps the turnover high, but also compensates for occasional food shortages or excessive densities of crabs. The next report will concentrate on the food spectrum of Cancer polyodon and the relative consumption of the different prey species.

Acknowledgements. This research was financially supported by project D.G.I. Universidad Catolica del Norte \# 68.71. Our sincere thanks go to M.Sc. Rachel Wolff and Dr Sabine Dittmann for their constructive suggestions, to Dr Thomas Brey for writing the bootstrap program and to 3 unknown referees, whose critical reading helped to improve the manuscript.

\section{LITERATURE CITED}

Asson-Batres, M. A. (1986). The feeding behaviour of the juvenile Dungeness crab, Cancer magister Dana, on the bivalve, Transenniella tantilla Gould, and a determination of its daily consumption rate. Calif. Fish Game 72(3): 144-152

Augsburger A., Vega, R. (1989). Transferencia de semillas del recurso ostion (Argopecten purpuratus) al medio natural. In: Estudio repoblamento de recursos bentonicos area piloto IV Region, II. Investigaciones especificas. Corp. de Fomento de la Produccion y Instituto Fomento Pesquero, Santiago, Chile, Ap 89/3b, p. 143-181

Bardach, J. E., Ryther, J H., McLarney, W O. (1972). Aquaculture: the farming and husbandry of freshwater and marine organisms. John Wiley \& Sons, New York

Barnes, R. S. K., Mann, K. H. (1980). Fundamentals of aquatic ecosystems. Blackwell Scientific Publications, Oxford

Branford, J. R. (1979). Locomotor activity and food consumption by the lobster (Homarus gammarus). Mar. Behav. Physiol. 6: 13-24

Caddy, J. F., Sharp, G. D. (1986). An ecological framework for marine fishery investigations. F.A.O. Fish. tech. Pap. 283

Chilton, N. B., Bull, C. M. (1986). Size-related selection of two intertidal gastropods by the reef crab Ozjus truncatus. Mar Biol. 93: 475-480

Dare, P. J., Edwards, D. B. (1976). Experiments on the survival, growth and yield of relaid seed mussels (Mytilus edulis L.) in the Menaia Straits, North Wales. J. Cons. int. Explor. Mer 37(1): 16-28

Davidson, R. J. (1986). Mussel selection by the Paddle crab Ovalipes catharus (White): evidence of flexible foraging behavior. J. exp. mar. Biol. Ecol. 102: 281-299

DiSalvo, L. H., Alarcon, E., Martinez, E., Uribe, E. (1984). Progress in mass culture of Argopecten purpuratus with notes on its natural history. Revta chil. Hist. nat. 57: 33-45

Efron, B. (1981). Nonparametric estimates of standard error. the jacknife, the bootstrap and other methods. Biometrika 68: $589-599$

Elbing, F. J., Kitching, J. A., Muntz, L., Taylor, M. (1964\}. XIII. Experimental observations of the destruction of Mytilus edulis and Nucella lapillus by crabs. J. Anim. Ecol. 33: $73-83$
Elliott, J. M., Persson, L. (1978). The estimation of daily rates of food consumption for fish. J. Anim. Ecol. 47: 977-990

Elner, R. W. (1978). The mechanics of predation by the shore crab, Carcinus maenas L., on the edible mussel, Mytilus edulis L. Oecologia 36: 337-344

Elner, R. W. (1981). Diet of green crab Carcinus maenas (L.) from Port Herbert, Southwestern Nova Scotia. J. Shellfish Res. 1(1): 89-94

Elner, R. W., Beninger, P. G., Linkletter, L. E. Lanteigne, S. (1985). Guide to indicator fragments of principal prey taxa in the stomachs of two common Atlantic crab species: Cancer borealis, Stimpson (1859) and Cancer irroratus. Say (1817). Can. tech. Rep. Fish. Aquat. Sci. 1403

Elner, R. W., Hughes, R. N. (1978). Energy maximization in the diet of the shore crab, Carcinus maenas. J. Anim. Ecol. 47: 103-116

Gotshall, D. W. (1977). Stomach contents of Northern Californian Dungeness crabs, Cancer magister. Calif. Fish Game 63(1): 43-51

Haddon, M., Wear, R. G. (1987). Biology of feeding in the New Zealand paddle crab Ovalipis catharus (Crustacea, Portunidae). N.Z. J. mar. freshwat. Res. 21: 55-64

Hill, B. J. (1976). Natural food, foregut clearance-rate and activity of the crab Scylla serrata. Mar. Biol. 34: 109-116

Jahnig, C. E. (1973). Growing the American lobster. Proc World Maricult. Soc. 4: 171-181

Jewett, S. C., Feder, H. M. (1982). Food and feeding habits of the king crab Paralithodes camischatica near Kodiak Island, Alaska. Mar. Biol. 66: 243-250

Krouse, J. S. (1972). Some life history aspects of the rockcrab, C. irroratus, in the Gulf of Maine. J. Fish. Res. Bd Can. 29: $1479-1482$

Lake, N. C. H., Jones, M. B., Paul, J. D. (1987) Crab predation of scallop (Pecten maximus) and its implication for scallop cultivation. J. mar. biol. Ass. U.K. 67: 55-64

Lane, E. D., Kingsley, M. C. S., Thornton, D. E. (1979). Daily feeding and food conversion efficiency of the diamond turbot: an analysis based on field data. Trans. Am. Fish. Soc. 108: $530-535$

Laughlin, R. A. (1982). Feeding habits of the blue crab Callinectes sapidus Rathbun, in the Apalachicola Estuary, Florida. Bull. mar. Sci. 32: 807-822

Mann, K. H. (1982). Ecology of coastal waters. Studies in ecology, Vol. 8. Univ. of California Press, Berkeley

Morales, C. Antezana, T. (1983). Diet selection of the Chilean stone crab Homalaspis plana. Mar. Biol. 77: 79-83

Paul, A. J., Fuji, A. (1989). Bioenergetics of the Alaskan crab Chionoecetes bairdi (Decapoda: Majidae). J. crust. Biol. 9(1): $25-36$

Perez, O. S., Bellwood, D. R. (1988). Ontogenic changes in the diet of the sandy shore crab Matuta lunaris (Forskal) (Brachyura: Calappidae). Aust. J mar freshwat. Res. 39: $193-199$

Polovina, J. J. (1984). Model of a coral reef ecosystem I. The ECOPATH model and its application to French Frigate shoals. Coral Reefs 3: 1-11

Rangeley, R. W., Thomas, M. L. H. (1987). Predatory behaviour of the juvenile shore crab Carcinus maenas (L.). J. exp. mar. Biol. Ecol. 108: 191-197

Scheibling, R. E. (1984). Predation by rock crabs (Cancer irroratus) on deseased sea urchins (Strongylocentrotus droebrachiensis) in Nova Scotia. Can. J. Fish. Aquat. Sci. 41. $1847-1851$

Steele, J. H. (1974). The structure of marine ecosystems. Harvard Univ. Press, Cambridge

Stevens, B. G., Armstrong, D. A., Cusimano, R. (1982). Feeding habits of the dungeness crab Cancer magister as 
determined by the index of relative importance. Mar. Biol. 72: $135-145$

Virnstein, R. W. (1977). The importance of predation by crabs and fishes on benthic infauna in Cheasapeake Bay. Ecology 58: 1199-1217

Williams, M. J. (1981). Methods for analysis of natural diet in portunid crabs (Crustacea, Decapoda, Portunidae). J. exp. mar. Biol. Ecol. 52: 103-113

Williams, M. J. (1982). Natural food and feeding in the commercial sand crab Portunus pelagicus (L.) (Crustacea,

This article was presented by J. E. Winter, Valdivia, Chile
Decapoda, Portunidae) in Moreton Bay, Queensland. J. exp. Mar. Biol. Ecol. 59: 165-176

Wolff, M. (1987). Population dynamics of the Peruvian scallop Argopecten purpuratus during the El Nino phenomenon of 1983. Can. J. Fish. Aquat. Sci. 44: 1684-1691

Wolff, M., Soto, M. (1992). Population dynamics of Cancer polyodon in La Herradura Bay, northern Chile. Mar. Ecol. Prog. Ser. 85: 69-81

Zipser, E., Vermeij, G. J. (1978). Crushing behavior of tropical and temperate crabs. J. exp. mar Biol. Ecol. 31. 155-172

Manuscript first received: February 15, 1992

Revised version accepted: October 13, 1992 